This is the post print version of the article, which has been published in International journal of retail \& distribution management 2018, 46 (11-12), 1133-1152.https://doi.org/10.1108/

IJRDM-08-2017-0167.

Yrjölä, M., Saarijärvi, H., \& Nummela, H. (2018). The value propositions of multi-, cross-, and omni-channel retailing.

D) This document has been downloaded from TamPub uta.fi

The Institutional Repository of University of Tampere

Author version

\title{
The value propositions of multi-, cross-, and omni-channel retailing
}

\begin{abstract}
Purpose - This study examines how retailers leverage multiple-channel strategies in relation to their customer value propositions (CVPs). More specifically, the purpose of this study is to identify and analyse how multi-, cross-, and omni-channel CVPs differ in terms of how they create value and which types of shopping motivations they aim to satisfy.

Design/methodology/approach - This conceptual paper presents and synthesizes three theoretical discussions pertaining to consumer shopping motivations, customer value propositions, and multiple-channel retailing strategies into a tentative conceptual framework. Nine case examples are used to illustrate three different channel strategies: multi-channel, cross-channel, and omni-channel retailing.
\end{abstract}

Findings - A tentative framework for understanding retailers' channel strategies is suggested. Practical implications - Retailers will benefit from a structured and synthesized understanding of the differences between multiple-channel strategies and their links to customer value propositions.

Originality/value - This paper introduces and integrates the concept of customer value propositions (CVPs) with the literature on multi-channel retailing strategies.

Keywords Customer value proposition, Customer value, Multiple-channel strategies, Omnichannel retailing

\section{Introduction}

Consumers today are presented with a myriad of opportunities through which they can search, compare, purchase, and obtain products. Newer technologies, business models, and predictive 
analytics are reshaping the boundaries of retailing, and as a result, retailers are provided with ample tools to generate differentiating value for customers and build deeper customer engagement (Grewal, et al., 2017). For instance, global e-commerce is expected to grow to approximately 4.5 billion dollars with an annual growth rate of around 10-15 percent (Statista 2018). In terms of product categories, fashion products, entertainment and consumer electronics drive online shopping, while 60-70 percent of consumers prefer buying grocery, furniture and homeware offline. Another outcome of the retail evolution is customers increasingly using various mobile devices to shop anywhere and at any time (e.g. Avery et al., 2012). This use of multiple channels by customers (Dennis et al., 2016) is the result of retailers using technology and partnerships to adopt multiple-channel strategies, that is, using various customer contact points or mediums through which the company and the customer interact (Neslin et al., 2006). The emerging multiple-channel strategies involve retailers adding new channels and utilizing and organizing them in various ways (e.g. Ansari et al., 2008; Geyskens et al., 2002) with the aim of building a unique customer experience (see Homburg et al., 2015). The strategies can be labelled multi-, cross-, or omni-channel retailing (Beck and Rygl, 2015; Verhoef et al., 2015).

Too often these strategies are presented and discussed interchangeably although fundamental differences exist in the way interaction between customers and retailers is coordinated and managed. What sets these strategies apart from one another is: how they enable customers to organize their own shopping processes encompassing multiple channels (a customer perspective) and how many and what types of channels are included (a retailer perspective) (Beck and Rygl, 2015; Berman and Thelen, 2004; Neslin et al., 2006; Zhang et al., 2010). Multiple-channel strategies with a high degree of integration can provide consistent promotions, products, and pricing across channels (Berman and Thelen, 2004). For instance, in cross- and omni-channel retailing, consumers can research products in-store, order them online, and pick them up from a dedicated collection point (Dennis et al., 2016). However, these types of seamless shopping processes, enabled by integrated retail business models, are rare because retailers face technological, processual, and organizational challenges (Zhang et al., 2010). A number of challenges to multiple-channel strategies have been identified in previous research and include data integration across channels, understanding customer behaviour through consumer analytics, channel evaluation and performance metrics, allocating resources across channels, coordinating channel strategies, and establishing a suitable organizational structure (Neslin et al., 2006; Piotrowicz and Cuthbertson, 2014; Wilding, 2013; Zhang et al., 2010; Yrjölä et al., in press). Consequently, without a clear and aligned focus, 
managing multiple-channel strategies can result in complexity and strategic misfits that endanger the very existence of the retailer.

As multi-, cross-, and omni-channel retailing all offer different shopping possibilities and processes, it is important not only to identify their conceptual and technological differences but to explore and uncover how and what type of value they can create for customers. A better understanding of customer value, that is, the perceived utilitarian and hedonic benefits and sacrifices of each multiple-channel strategy, can guide retailers' areas of scope, focus, competence development, and resource allocation as well as help them align their multiplechannel strategies with their raison d'être. Altogether, through better understanding of multiple-strategies' characteristics, challenges, and opportunities, retailers can make more informed channel-strategy decisions. To address this contemporary challenge, this study examines how retailers leverage multiple-channel strategies in relation to their customer value propositions (CVPs). More specifically, the purpose of this study is to identify and analyse how multi-, cross-, and omni-channel CVPs differ in terms of how they create value and which types of shopping motivations they aim to satisfy.

The article is organized as follows. First, three theoretical discussions pertaining to consumer shopping motivations, customer value propositions, and multiple-channel retailing strategies are presented and synthesized into a tentative conceptual framework. Second, the methodology including the selection of the nine case examples is described. Third, the findings resulting from the interplay between the case examples and the tentative conceptual framework are presented and discussed. Conclusive remarks include limitations and future research opportunities.

\section{Theoretical background}

The conceptual nature of the study requires building a theoretical basis that is well aligned with the dynamics of the evolving research phenomenon, that is, retailers employing diverse multiple-channel strategies. In this endeavour, three complementary theoretical discussions are harnessed. First, the discussion around customer value propositions offers a conceptual tool to understand companies' responses to evolving customer needs that are driven by various shopping motivations. Second, utilitarian and hedonic shopping motivations reveal what drives consumer behaviour. And third, multiple-channel strategies ought to be considered subordinate to above; they are vehicles for delivering customer value propositions. Most importantly, in the context of this study, these three theoretical discussions are well aligned with the study purpose and, together, contribute to the building of the theoretical framework. 


\section{Customer value propositions}

Customer value propositions (CVPs) capture what kind of value (or benefits) the retailer offers its customers and through what means this value is created. More specifically, a CVP is defined as "a competitive statement of the dimension of value offered to a specific group of customers, the ways in which the firm creates value, and reasons for customers to select the firms' offering" (Yrjölä, 2015, p. 30).

To put it simply, the CVP defines who the customers are (Day and Moorman, 2010; Johnson et al., 2008). As such, retailers will benefit from identifying the customers' shopping motivations, whether they are more utilitarian or more hedonic (see Rintamäki et al., 2007), and incorporating them into the CVP. This is often done by expressing the few concrete benefits that are relevant to customers (Anderson et al., 2006; Day and Moorman, 2010). In this discussion, points of parity refer to benefits that are shared by competitors but appreciated by customers, and points of difference refer such favourable benefits that competitors don't offer (Anderson et al., 2006). Thus, a CVP points out the reason why customers should choose the retailer's offerings as opposed to those of its competitors.

In addition to being an external tool for positioning the retailer in the marketplace, the CVP can internally guide the organization's efforts. It guides how the value is created, for example, through which channels the retailer interacts with its customers, and in which ways the interaction takes place. All this affects the organization's choices for resource allocation, capability development, and business model innovation, highlighting the need to understand how retailers are employing multiple-channel strategies to carry out their CVPs.

\section{Utilitarian and hedonic shopping motivations in the multiple-channel environment}

As mentioned above, retailers' CVPs should resonate with the target consumer segment's shopping motivations. Understanding consumers' shopping motivations is a critical objective as it drives behaviour (e.g. Childers et al., 2001; Scarpi et al., 2014). These motivations are broadly categorized as being either more utilitarian or more hedonic in nature (Arnold and Reynolds, 2003; Childers et al., 2001; Sánchez-Fernández and Iniesta-Bonillo 2007). Utilitarian motivations can be characterized as task-related, rational, and focused on whether or not the consumer can successfully acquire a product (Batra and Ahtola, 1991; Babin et al., 1994). Hedonic motivations, in turn, include the emotive, multisensory, and fantasy aspects of consumption (Babin et al., 1994; Hirschman and Holbrook, 1982). Thus, the focus of hedonic motivations is usually on the shopping experience itself, independent of task-related 
acquisitions (Jones et al., 2006), while utilitarian motivations view shopping as a means to an end (Sánchez-Fernández and Iniesta-Bonillo, 2007).

The target customers' shopping motivations clearly influence how a retailer should position its CVP and how it can use different multiple-channel strategies to deliver relevant customer benefits. Retailers positioning themselves to cater to more utilitarian motivations can base their value propositions on elements such as broad assortments, low pricing, and extended store hours (Arnold and Reynolds, 2003). These utilitarian elements can be characterized as relatively concrete and generally focus on decreasing sacrifices for customers, for example, through saving the customer's time or effort (Rintamäki et al., 2007). Retailers catering to hedonic motivations can build their value propositions on more abstract elements such as adventure, identity, or inspiration (Arnold and Reynolds, 2003; Holbrook, 1999). While new channels (such as the Internet) provide a wide array of utilitarian benefits, such as 24-hour service, easy search functions, and the ability to quickly compare hundreds of retailers, they have also been shown to cater to more hedonic motivations, such as creating an immersive experience (Childers et al., 2001; Overby \& Lee, 2006).

Consequently, considering both the utilitarian and hedonic shopping motivations provides a theoretical means for exploring in depth the type of value propositions different multiple-channel retail strategies offer. Recent studies have used and refined the concepts of utilitarian and hedonic shopping motivations to uncover elements and antecedents of online retail experience or to compare online and offline experiences (see e.g. Bridges \& Florsheim, 2008; Childers et al., 2001; Kawaf and Tagg, 2017; Overby \& Lee, 2006; O’Brien, 2010; Trevinal and Stenger, 2014). A related approach conceptualizes the overall consumer experience in terms of customers' cognitive and affective perceptions (Pappas et al., 2016; Trevinal and Stenger, 2014). Both of these notions are based on Hirschman and Holbrook's (1982) notion of consumers as either "problem solvers" or seeking "fun, fantasy, arousal, sensory stimulation, and enjoyment". However, while utilitarian and hedonic shopping motivations have been linked with research on online retailing experience, only limited attention has been paid to understanding its role in driving retailers' multiple-channel strategies. As suggested by Kwon and Jain (2009), understanding these motivations in a multiple-channel context would though help retailers to attract shoppers across different channel options and configurations. Traditionally, the online channel has been thought to primarily serve utilitarian shopping motivations (e.g. convenience, price comparisons, product information), but research has shown that it offers opportunities for retailers to create both cognitively and aesthetically rich shopping environments (Childers et al., 2001; Overby \& Lee 
2006; Scarpi et al., 2014). Nevertheless, there still remains experiential potential in combining the benefits of both offline, online and mobile channels (Rigby, 2011). In that respect, consumers utilize a selection of channels through which the access and create retail experiences. For consumers the channels are thus a means to create a desired shopping experience, whether driven by utilitarian or hedonic shopping motivations.

\section{Multiple-channel retailing strategies}

Retailers can employ communication, sales, and customer service channels in various ways. Previous research has distinguished between three different multiple-channel strategies that depend on how channel interaction and channel integration are orchestrated: multi-channel, cross-channel, and omni-channel retailing.

First, multi-channel retailing is "the set of activities involved in selling merchandise or services through more than one channel or all widespread channels, whereby the customer cannot trigger channel interaction and/or the retailer does not control channel integration" (Beck and Rygl, 2015, p.174). Thus, multi-channel retailing represents the strategy with the least amount of customer control over channel interaction and retailer control over channel integration. Multi-channel strategies were originally established as a means for traditional retailers to enter electronic commerce competition. New channels were added and operated as separate entities with separate management and channel-specific objectives (Chatterjee, 2010b; Verhoef et al., 2015). These developments resulted in confusing pricing policies, promotions, and brand building between channels, ultimately producing lacklustre consumer experiences (Wilding, 2013). In the worst cases, a retailer's two channels might even compete directly with each other (Piotrowicz and Cuthbertson, 2014).

Second, cross-channel retailing can be defined from the customer's or the retailer's point of view (Beck and Rygl, 2015). From the customer's point of view cross-channel retailing enables the customer to trigger either partial channel interaction through all widespread channels or full interaction through more than one channel but not all widespread channels. From the retailer's point of view, it involves control of partial channel integration through all widespread channels or full integration through a limited number of channels (Beck and Rygl, 2015). This involves cross-channel movements of products, money, and information (Chatterjee, 2010b). Thus, cross-channel retailing is characterized by partial channel interaction and/or partial channel integration. Retailers adopting a cross-channel strategy are motivated by the prospect of establishing synergies across channels (e.g. Avery et al., 2012; Neslin et al., 2006; Zhang et al., 2010) and thereby increasing repurchase intentions (Bell et 
al., 2015; Chatterjee, 2010a). Examples of a cross-channel strategies include ordering online and picking up in-store, ordering in-store and getting the product delivered to the home, and returning online purchases in-store (Chatterjee, 2010b).

Third, omni-channel retailing is defined as "the set of activities involved in selling merchandise or services through all widespread channels, whereby the customer can trigger full channel interaction and/or the retailer controls full channel integration" (Beck and Rygl, 2015, p.175). This strategy is centred on a holistic view of all channels (Brynjolfsson et al., 2013). From the customer's point of view, he/she can move seamlessly from one channel to another, including the widespread channels such as a manufacturer's website, retailer app, and a pick-up point. Even traditional mass marketing channels are considered part of this strategy and therefore, also require synergetic management (Verhoef et al., 2015). Moreover, different channels interact with each other and are often used simultaneously in creating the customer experience (Verhoef et al., 2009; Verhoef et al., 2015). Thus, in comparison to other multiplechannel strategies, customers receive added benefits such as information visibility, cost savings, or convenience (Piotrowicz and Cuthbertson, 2014). Further, the focus is on the interaction between the customer and the retailer's brand, not between the customer and a specific channel (Piotrowicz and Cuthbertson, 2014).

\section{Preliminary conceptual framework}

Building on the above theoretical discussion, a preliminary framework for analysing customer value creation through multiple-channel retail strategies was constructed. This framework is presented in Figure 1.

\section{INSERT FIGURE 1 HERE}

In order to craft and position successful CVPs, retailers first need to understand consumers' various shopping motivations, which can broadly be categorized as either utilitarian or hedonic. For instance, if the retailer is targeting consumers with more utilitarian shopping motivations (i.e. shopping as a means to an end) (Batra and Ahtola, 1991; Babin et al., 1994; Sánchez-Fernández and Iniesta-Bonillo, 2007), one possibility is to offer a CVP that reduces consumers' rational and process-related sacrifices, making the shopping process easier. Next, the retailer should determine the CVPs points of parity and difference relative to competitors. For example, a retailer targeting consumers with more hedonic shopping 
motivations (i.e. motivations that relate to the emotive, multisensory, and fantasy aspects of consumption) (Babin et al., 1994; Hirschman and Holbrook, 1982) might build points of difference around memorable shopping experiences. Finally, the retailer's multiple-channel strategies should be aligned with the CVP and consumer shopping motivations in order to create relevant benefits or reduce sacrifices for the retailer's customers.

\section{Methodology}

To understand how retailers leverage different channels and orchestrate interaction and integration, the current paper focuses on example cases from various global retail contexts. Given the explorative nature of the study, using these focused case examples, or vignettes (e.g. Reinartz et al., 2011; Saarijärvi et al., 2014), to illustrate the usage of multiple-channel strategies can be considered a suitable strategy for understanding the interplay between a novel phenomenon and its context (see Dubois and Gadde, 2002). These case examples facilitate the understanding of the phenomenon by generating new insights into the issues related to retail channel strategies and customer value. Hence, the cases themselves are of secondary interest next to the understanding of the focal phenomenon (Stake, 2005). These multiple-case examples offer preliminary and tentative empirical insights into the ways in which retailers utilize different channels to offer customer value, and they were considered an effective research strategy to outline and explore the central characteristics of the research phenomenon (see Rubalcaba et al., 2012; Nordin and Kowalkowski, 2010), that is, retailers' use of multiplechannel strategies.

\section{Data generation}

Retailing is an increasingly global and dynamic business context, which is why the selection of the cases was not limited to a specific retailing category or country. The overarching focus was on identifying examples that characterized and reflected the use of multiple channels in rich and diverse ways. The data generation process consisted of three phases (Figure 2) that took place between 1 September and 31 December, 2016.

\section{INSERT FIGURE 2 HERE}

First, a broad search was executed to become familiar with the research phenomenon and identify the most suitable information sources, search terms, and keywords. This phase involved using search engines and scholarly sources to understand the nature of the evolving 
landscape. Examples of the keywords used in different phases of the data generation process are listed in Appendix I. This phase resulted in identifying 11 suitable case examples reflecting retailers' use of multiple-channel strategies.

Second, a complementary search was executed by reviewing scientific articles, consultant reports, blogs, and forums using the suitable keywords identified in the first phase. This resulted in the identifying an additional 8 case examples, with a total of 19 cases (Appendix II). Instead of identifying as many suitable case examples as possible, focus was also on identifying such cases that could highlight the differences between multi-, cross-, and omni-channel retailing and the customer value the different channel strategies provided. The objective was to generate a set of case examples that best illustrated the various ways in which retailers utilize different channel strategies to serve their customers.

Third, the identified case examples were augmented by a systematic search involving the retailer's own websites and application stores. This included collecting general information about the company, its customer value proposition, and channel strategies. In particular, data was collected regarding the general purpose of the chosen channel strategy: why it was established, at whom it was targeted, and how it was meant to be used by customers. These questions guided the case specific data generation process; that is, they provided the empirical lens through which the cases were viewed. As a result, summarized and commensurable descriptions of each case example was generated resulting in 19 case descriptions. During this phase, the authors assessed, compared, and discussed each of the cases identified in the previous phases and excluded parallel and similar examples. Finally, nine examples were selected for further analysis. The chosen cases were considered to characterize the distinct nature of different channel strategies while also representing a broad range of different retailing contexts. Although the search was not limited geographically, these case examples were established by different retailers from Europe and North America.

\section{Data analysis}

Analysis is needed to give data significance, to outline what the phenomenon is about and how it works (Corbin and Strauss, 2008). To address the study purpose, multiple cases were analysed to elicit contextualized patterns, mechanisms, and characteristics of the research phenomenon. Thus, the cases themselves are not in focus, but they enable a deeper understanding of the research phenomenon (Eriksson and Kovalainen, 2008; Gummesson, 2005). 
First, each case description was explored and discussed among the authors to understand how retailers were employing multiple-channel strategies to create value for customers. This included considering the stated purposes and benefits of the retailers' technologies and channels. Overall, during the first phase, the authors accumulated shared understanding of the basic characteristics of the channel strategy of each case example.

Second, a more formal analysis was conducted using content analysis techniques such as classification. In this phase, the case examples were compared against each other to better understand their differences and fundamental characteristics. Different points of departure to the case examples were systematically employed to facilitate the analysis process. These included, for example, the general nature and logic of the multiple-channel strategy employed, the locus of customer value proposition, and concrete examples of the multiple-channel use. These perspectives accounted for the analytical lens through which each case was viewed. The patterns capturing the research phenomenon were iteratively developed, refined, and adjusted. The overarching focus was on uncovering the logic behind different retailers' channel strategies, their fundamental characteristics, and the type of solution offered to customers (including the benefits provided and the customer sacrifices mitigated). This all served to answer the overarching purpose of uncovering how different multiple-channel strategies help retailers better serve their customers.

Nine illustrative case examples were chosen: Power (consumer electronics), Masku (furniture and decoration), Nanso Group (fashion and accessories), The Home Depot (DIY and renovation), Oasis (fashion), REI (outdoor and camping), Waitrose (groceries), Jordan's Furniture (furniture and decoration), and Rebecca Minkoff (fashion). Using the classification by Beck and Rygl (2015), the cases were categorized as either multi-, cross-, or omni-channel retailers based on how they described their channel offering and functionality. For instance, retailers not offering product pick-ups or returns across their channels were categorized as employing a multi-channel strategy.

Third, the analysis process involved reflecting on the cases with the tentative conceptual framework. In that respect, the process of data analysis was more cyclical than linear in nature. In line with the abductive logic (as opposed to deductive or inductive logic of inquiry) (Eriksson and Kovalainen, 2008), both theory and empirical data played important roles in the research process (Alvesson and Sköldberg, 2000; Dubois and Gadde, 2002; Gummesson, 2000). Thus, the research process involved constant movement between theory and empirical reality. 


\section{Findings and discussion}

The chosen illustrative case examples, along with their theoretical classifications, are presented in table 1.

\section{INSERT TABLE 1 HERE}

The findings are summarized in Table 2, which presents the locus of value propositions, examples of channel benefits, and channel-strategy characteristics.

\section{INSERT TABLE 2 HERE}

\section{CVPs in multi-channel retailing}

Based on the case examples, those retailers operating under a multi-channel strategy, were focused on product-related aspects in their value propositions (rather than shopping processrelated aspects, for example). This was evident in the retailers emphasizing benefits like wide selections, low prices, superior products, or high quality. To a large extent, these benefits reflect utilitarian motives, but the Finnish fashion and accessory retailer, Nanso, also offered more hedonic benefits such as timeless design and expressive patterns in the products.

For multi-channel retailers, the additional channels did not emerge as new means for value creation in the value proposition. Rather, the focus was on the product-related benefits in different channels. For instance, the Nordic consumer electronics retailer, Power, emphasized to its customers that its prices do not differ across channels ("the same low prices both online and in the stores"). However, from the customer's point of view, different channels can be seen as altogether different places to shop. For example, the furniture and décor retailer, Masku, did not offer customers the option of picking up online purchases from stores, and gift cards were channel-specific. In the case of Nanso, online and offline channels even had their own, separate loyalty programs.

In sum, in the light of the case examples, value creation in multi-channel retailing is about offering (mostly utilitarian) product- or brand-centred benefits to customers in different channels. Channels are secondary in importance to the retailer's assortment, features, and pricing of products. 


\section{CVPs in cross-channel retailing}

Retailers employing a cross-channel strategy focused on the shopping process-related aspects in their value propositions. For instance, retailers emphasized terms such as fun, relaxation, convenience, service, education, and inspiration. The customers' process-related shopping motivations can be both utilitarian (e.g. shopping as a convenient process) as well as hedonic (e.g. shopping as a rewarding pastime activity).

Cross-channel retailers striving to serve customers with utilitarian motivations are finding ways to make the customer's shopping process easy and convenient. They are increasingly focusing on product logistics, product comparisons, and transactions. Increasing convenience in product logistics involves enabling customers to pick up or return online orders to a physical store or even encouraging in-store showrooming behaviour by focusing all transactions in the online channel, like American clothes retailer, Bonobos. The UK-based retailer Tesco enables customers to pick up their online orders from physical stores and for grocery orders, the customer can even designate their preferred pick-up time. Cross-channel product comparisons, mobile transactions, and electronic receipts are other examples of a cross-channel strategy delivering utilitarian benefits. An illustrative example of such a value proposition focusing on service excellence is The Home Depot, an American retailer offering do-it-yourself (DIY) and renovation products, materials, and services. The retailer has online, mobile, and offline channels that are integrated in functionality. For instance, The Home Depot's mobile app functions well with physical stores; mobile purchases can be picked up from the stores, the app can locate the nearest store, and features the store layout for helping customers find the products they are looking for. Also, the application's bar code scanner enables customers to read product reviews. Another interesting cross-channel use of mobile application is used by the UK-based department store chain John Lewis: the smartphone app, among other features, can be used to notify John Lewis of competitor prices.

Those cross-channel retailers targeting customers with hedonic motivations focus on making the shopping process itself a rewarding, value-adding activity. For instance, fashion retailer, Oasis' mobile application lets customers familiarize themselves with Oasis' unique prints, read other customers' reviews, and watch fashion show videos for inspiration; while in stores, customers can take advantage of the services of a personal stylist. As another example, Recreational Equipment, Inc. (REI), an American outdoor and sports equipment retailer, also offers customers expert advice and inspiration across two online stores, a mobile application, a phone and mail order service, and physical stores. Like Oasis, REI's mobile app enables 
customers to browse product information (availability, pictures, and technical details), customer reviews, and product videos. Customers can also use the app to contact clerks, and in store, the app can be used to scan barcodes and look up more detailed information on the product or add it to their wish list. In-store employees all have mobile devices for looking up product information or checking availability. Similarly, the French cosmetics retailer, Sephora offers make-up lessons and personal expert appointments in-store, while the mobile app features tutorials, product reviews, recommendations and demonstrations, and lessons in makeup techniques. The app also includes a "virtual artist" function that enables virtual product testing.

In sum, value creation in cross-channel retailing is about offering the customer a distinctive, value-adding shopping process. The retailer's channels not only add convenience and customer control over this process, they also provide unique benefits such as expert advice (store), product comparisons (online), and product tutorials (mobile). At the same time, it is important that each channel delivers the same level of customer service, product information, and knowledge to avoid customer confusion.

\section{CVPs in omni-channel retailing}

Based on the analysed case examples, omni-channel retailers seem to focus on the experiential (hedonic) aspects of consumption in their value propositions. Shopping is seen as a pleasurable pastime activity involving spending time with the retailer brand (see also Frasquet et al., 2017) and experiencing memorable events. The use of new technology in conducting these experiences is evident in most of the cases. For example, Apple's customers can make voicecontrolled purchases at home through their Apple TV, while Neiman Marcus' mobile app enables customers to take a photo of a clothing item or accessory to see whether Neiman Marcus offers anything similar. As another example, Rebecca Minkoff's omni-channel strategy to deliver a "seamless" shopping experience is evident in its New York flagship store featuring digital fitting rooms. These fitting rooms, provided in partnership with eBay, have digital screens that enable customers to contact clerks, browse product information, view their product history, and add products to their personal wish lists and favourites. Further hedonic benefits are created when the customers use these screens to order beverages (e.g. coffee, tea, or champagne), adjust the lighting (e.g. nightclub lighting), or receive complementary product recommendations. All data from these interactions is recorded, and the customer can access it via the online site or the Rebecca Minkoff mobile application. Rebecca Minkoff also offers a virtual fitting room application. Similarly, upscale or high-end department stores, such as 
Nordstrom, Bloomingdale's or Neiman Marcus, are adding digital mirrors to enhance the customer's in-store experiences. These digital mirrors enable customers to record a $360^{\circ}$ image of themselves to compare outfits more easily. The mirrors also offer complementary product recommendations, and recorded videos can be shared with friends.

Value propositions targeting hedonic consumption can also involve the retailer supporting the customer's lifestyle. For instance, Waitrose aims to help its customers make healthier choices (a healthy lifestyle). This involves utilizing new technologies that enable the customer to check each product's source and ingredients. Waitrose's physical stores feature dining areas and juice bars, from which the customers can pre-order refreshments for their shopping trips. The stores also have interactive digital kiosks that, for example, include product information and recommendations for wines, while in-store tablet devices enable customers to order food and confections to go. To enable a seamless customer experience, customer data is shared among channels.

The New England-based furniture retailer, Jordan's Furniture, offers customers "shopper-tainment," meaning a hedonic, memorable shopping experience that is more than a mere store visit. For example, the company's "Room Planner" application lets customers design rooms and try out furniture placement, colours, sizes, and materials before purchase. The customer can then download the designs as a shopping list. The physical store environment consists of different "streets," each with their own themes, features services, and experiences such as restaurants, an IMAX 3D movie theatre, laser light shows, and driving simulations. As another example, the French home electronics retailer, Boulanger utilizes digital displays and a tablet at the entrance of its Parisian flagship store so customers can let the company know their reason for visiting, while the products displayed have electronic barcodes enabling customers to compare prices and read consumer reviews.

To sum up, value creation in omni-channel retailing involves consideration of the customer experience in larger terms than a single transaction or shopping process. Channel boundaries are removed to enable full customer interaction with the retailer, but, perhaps surprisingly, less focus is put on offering the same features in all channels. Rather, more effort is placed on orchestrating meaningful customer-brand interactions. One key feature of such a strategy is personalization of the shopping experience.

\section{Conclusion}

Digitization is reconfiguring the opportunities for value creation in all industries. As a result, various multiple-channel strategies have emerged that drive contemporary retail evolution. 
Retailers today are developing, testing, failing, and succeeding in diverse multi-, cross-, and omni-channel initiatives. Despite their critical importance, too often multiple-channel strategies are built without further consideration and links to companies' raison d'être or customer experience (Homburg et al., 2015). This can result in digitization without clear purpose. To address this concern, the purpose of this study was to identify and analyse how multi-, cross-, and omni-channel CVPs differ in terms of how they create value and which types of shopping motivations they aim to satisfy. Linking theoretical discussion around consumer shopping motivations and CVPs with the multiple-channel categorization by Beck and Rygl (2015), a conceptual framework was proposed (Figure 1) and further reflected upon with selected case examples that illustrated various multiple-channel strategies used by different retailers. This resulted in linking multiple-channel strategies employed with the locus of value propositions, channel specific benefits, and channel strategy characteristics (Table 2). On the basis of these results, we put forth three implications.

First, while some literature states that an omni-channel retailing strategy is likely to lead to a competitive advantage (Brynjofsson et al., 2015; Rigby, 2011; Verhoef et al., 2015), this study suggests that all multiple-channel strategies can generate such advantages. One-sided focus toward omni-channel initiatives can easily lead the retailer astray and cause unnecessary investments. More importantly, retailers should evaluate and assess their multiple-channel strategies in relation to their CVPs and focus on aligning them accordingly.

Second, it is interesting to note that the role of the customer changes across different multiple-channel strategies. Specifically, when comparing multi-channel to cross- or omnichannel strategies, the role of the customer seems to change from a passive recipient to a more active participant in the shopping process. Theoretically, this is reflected in the change toward value co-creation, where the role of companies is to support customers' own value-creating processes (Payne et al., 2008; Saarijärvi et al., 2014).

Third, in addition to customer shopping motivations, the product category is likely to influence the most effective multiple-channel strategy. In high-involvement purchases involving complex products, strategies focusing on the customer's shopping process might be more effective (i.e. cross-channel) than those focused on experiential aspects (i.e. omnichannel).

Like all studies, this one is not without its limitations. First of all, it should be noted that the concepts of multiple-channel strategies and customer value are both under some debate in the literature, with some definitions highlighting certain aspects while downplaying others. Similarly, the real-world case examples do not fit neatly into theoretical categorizations. For 
instance, the line between cross- and omni-channel retailers is sometimes hard to distinguish. Additionally, most retailers offer both utilitarian and hedonic aspects in their customer value propositions. Thus, an effort was made to choose examples that best illustrated some aspect under consideration, for instance regarding a cross-channel strategy.

Second, this study relied purely on secondary public data about the retailers. An indepth case study of one or two organizations would yield differing insights on how channels are internally managed and integrated. Additionally, retailers' explicit slogans, advertising, brands, and value propositions were used in determining whether a retailer's emphasis was utilitarian or hedonic. Naturally, these might not fully reflect what is actually done to serve customers or how the customers ultimately perceive the offerings.

Third, the research findings from qualitative research are always dependent on context and time. Thus, caution should be used in generalizing the findings. To remedy this, the chosen examples were not limited to one geographic region or language area. Further, the retailers represent a wide range of product and service categories with different customer groups.

This paper opens up interesting possibilities for future research. First of all, more research examining the link between customer value propositions and different multiplechannel strategies is needed. For instance, a quantitative study could examine the effects of product category and product range on the chosen strategy and value proposition emphasis. Second, as customer value is ultimately defined by the customer, a study from the customer's subjective perspective would yield insights into the benefits different channel strategies yield and through which processes. In-depth interviews or focus group discussions could be utilized to gain such insights. Third, as mentioned above, an in-depth case study of one organization could yield insights on how channels are internally managed and integrated. Such a study could also be a longitudinal one analysing the process where a retailer changes its channel strategy from multi- to cross-channel or from cross- to omni-channel retailing. It would produce more understanding of the factors involved and the requirements of such a change, for example, resources, capabilities, leadership, vision, or business models. 


\section{References}

Alvesson, M., and Sköldberg, K. (2000), Towards a reflexive methodology, Sage, London.

Anderson, J. C., Narus, J. A., and Van Rossum, W. (2006), "Customer value propositions in business markets", Harvard business review, Vol. 84 No. 3, pp. 90-99.

Ansari, A., Mela, C. F., and Neslin, S. A. (2008), "Customer channel migration”, Journal of Marketing Research, Vol 45 No. 1, pp. 60-76.

Arnold, M. J., and Reynolds, K. E. (2003), "Hedonic shopping motivations", Journal of retailing, Vol. 79 No. 2, pp. 77-95.

Avery, J., Steenburgh, T.J., Deighton, J., and Caravella, M., (2012), “Adding bricks to clicks: predicting the patterns of cross-channel elasticities over time", Journal of Marketing, Vol. 76 No. 3, pp. 96-111.

Babin, Barry J., Darden, William R., and Griffin, Mitch. (1994), "Work and/or fun: Measuring hedonic and utilitarian shopping value", Journal of Consumer Research, Vol.20 No. 4, pp. $644-656$.

Batra, R., and Ahtola, O. (1991), "Measuring the hedonic and utilitarian sources of consumer attitudes", Marketing Letters, Vol. 2 No. 2, pp. 159-170.

Beck, N., and Rygl, D. (2015), "Categorization of multiple channel retailing in Multi-, Cross-, and Omni-Channel Retailing for retailers and retailing”, Journal of Retailing and Consumer Services, Vol. 27, No. 170-178.

Bell, D. R., Gallino, S., and Moreno, A. (2015), "Offline showrooms and customer migration in omni-channel retail", available at SSRN: http://ssrn.com/abstract=2370535 (accessed 15 May 2017).

Berman, B., and Thelen, S. (2004), "A guide to developing and managing a well-integrated multi-channel retail strategy", International Journal of Retail \& Distribution Management, Vol. 32 No. 3, pp. 147-156.

Bridges, E. and Florsheim, R. (2008), "Hedonic and utilitarian shopping goals: The online experience", Journal of Business Research, Vol. 61 No. 4, pp. 309-314. 
Brynjolfsson, E., Hu, Y.J., and Rahman, M.S. (2013), "Competing in the age of omni-channel retailing”, MIT Sloan Management Review, Vol. 54 No. 4, pp. 23-29.

Chatterjee, P. (2010a), "Causes and consequences of 'order online pick up in-store' shopping behavior", International Review of Retail, Distribution \& Consumer Research, Vol. 20 No.4, pp. $431-438$.

Chatterjee, P. (2010b), "Multiple-channel and cross-channel shopping behavior: role of consumer shopping orientations", Marketing Intelligence \& Planning, Vol. 28 No. 1, pp. 9-24.

Childers, T. L., Carr, C. L., Peck, J. and Carson, S. (2001), "Hedonic and utilitarian motivations for online retail shopping behavior", Journal of retailing, Vo. 77 No. 4, pp. 511-535.

Corbin, J., \& Strauss, A. (2008), Basics of qualitative research, 3rd edition, Sage, London.

Day, G. and Moorman, C. (2010), Strategy from the outside in: Profiting from customer value, McGraw Hill Professional, New York.

Dennis, C., Alamanos, E., Papagiannidis, S. and Bourlakis, M. (2016), "Does social exclusion influence multiple channel use? The interconnections with community, happiness, and wellbeing”, Journal of Business Research, Vol. 69 No. 3, pp. 1061-1070.

Dubois, A. and Gadde, L.-E. (2002), "Systematic combining: an abductive approach to case research", Journal of Business Research, Vol. 55 No. 7, pp. 553-560.

Eriksson, P. and. Kovalainen, A. (2008), Qualitative Methods in Business Research, Sage, London.

Frasquet, M., Descals, A.M. and Ruiz-Molina, M.E. (2017), "Understanding loyalty in multichannel retailing: the role of brand trust and brand attachment", International Journal of Retail \& Distribution Management, Vol. 45 No. 6, pp. 608-625.

Geyskens, I., Gielens, K., and Dekimpe, M. G. (2002), "The market valuation of internet channel additions", Journal of Marketing, Vol. 66 No. 2, pp. 102-119.

Grewal, D, Roggeveen, A.L. and Nordfält, J. (2017), "The future of retailing”, Journal of Retailing, Vol. 93 No. 1, pp. 1-6.

Gummesson, E. (2005), "Qualitative research in marketing: Road-map for a wilderness of complexityand unpredictability", European Journal of Marketing, Vol. 39 No. 3/4, pp. 309327. 
Hirschman, E.C. and Holbrook, M.B. (1982), "Hedonic consumption: Emerging concepts. Journal of Marketing", Vol. 46 No. 3, pp. 92-101.

Holbrook, M. B. (1999), Consumer value: a framework for analysis and research, Psychology Press.

Homburg, C., Jozić, D., \& Kuehnl, C. (2015), “Customer experience management: Toward implementing an evolving marketing concept", Journal of the Academy of Marketing Science, doi: 10.1007/s11747-015-0460-7.

Johnson, M. W., Christensen, C. M., and Kagermann, H. (2008), "Reinventing your business model", Harvard business review, Vol. 86 No. 12, pp. 57-68.

Jones, M. A., Reynolds, K. E., and Arnold, M. J. (2006), "Hedonic and utilitarian shopping value: Investigating differential effects on retail outcomes", Journal of Business Research, Vol. 59 No. 9, pp. 974-981.

Kawaf, F. and Tagg, S. (2017), "The construction of online shopping experience: A repertory grid approach”, Computers in Human Behavior, Vol. 72 (July), pp. 222-232.

Khalifa, A.S. (2004), "Customer value: a review of recent literature and an integrative configuration”, Management decision, Vol. 42 No. 5, pp. 645-666.

Kwon, K.-N., and Jain, D. (2009), "Multichannel shopping through non-traditional retail formats: Variety-seeking behaviour with hedonic and utilitarian motivations", Journal of Marketing Channels, Vol. 16 No. 2, pp. 149-168.

Neslin, S.A., Grewal, D., Leghorn, R., Shankar, V., Teerling, M.L., Thomas, J.S., and Verhoef, P.C. (2006), "Challenges and opportunities in multichannel customer management", Journal of Service Research, Vol. 9 No. 2, pp. 95-112.

Nordin, F. and Kowalkowski, C. (2010). "Solutions offerings: a critical review and reconceptualization”, Journal of Service Management, Vol. 21 No. 4, pp. 441-459.

O'Brien, H.L. (2010), “The influence of hedonic and utilitarian motivations on user engagement: The case of online shopping experiences", Interacting with Computers, Vol. 22 No. 5, pp. 344-352. 
Overby, J.W. and Lee, E.-J. (2006), "The effects of utilitarian and hedonic online shopping value on consumer preference and intentions", Journal of Business Research, Vol. 59 Nos. 1011, pp. 1160-1166.

Pappas, I.P, Kourouthanassis, P. E., Giannakos, M.N. and Chrissikopoulos, V. (2016), "Explaining online shopping behaviour with fsQCA: The role of cognitive and affective perceptions", Journal of Business Research, Vol. 69 No. 2, pp. 794-803.

Payne, A. F., Storbacka, K., and Frow, P. (2008), "Managing the co-creation of value", Journal of the academy of marketing science, Vol. 36 No. 1, pp. 83-96.

Piotrowicz, W. and Cuthbertson, R. (2014), "Introduction to the special issue - Information technology in retail: Towards omni-channel retailing", International Journal of Electronic Commerce, Vol. 18 No. 4, pp. 5-16.

Reinartz, W., Dellaert, B., Krafft, M., Kumar, V. and Varadarajan, R. (2011), "Retailing innovations in a globalizing retail market environment", Journal of Retailing, Vol. 87 No.1, pp. S53-S66.

Rigby, D. (2011), “The future of shopping”, Harvard Business Review, Vol. 89 No. 12, pp. 6576.

Rintamäki, T., Kanto, A., Kuusela, H. and Spence, M. T. (2006), "Decomposing the value of department store shopping into utilitarian, hedonic and social dimensions: Evidence from Finland", International Journal of Retail \& Distribution Management, Vol. 34 No. 1, pp. 6-24.

Rintamäki, T., Kuusela, H., and Mitronen, L. (2007), "Identifying competitive customer value propositions in retailing”, Managing Service Quality: An International Journal, Vol. 17 No. 6, pp. 621-634.

Rubalcaba, L., Michel, S., Sundbo, J., Brown, S.W. and Reynoso, J. (2012), "Shaping, organizing, and rethinking service innovation: a multidimensional framework", Journal of Service Management, Vol. 23 No.5, pp. 696-715.

Saarijärvi, H., Mitronen, L. and Yrjölä, M. (2014), "From selling to supporting - Leveraging mobile services in the context of food retailing", Journal of Retailing and Consumer Services, Vol. 21 No. 1, pp. 26-36.

Sánchez-Fernández, R. and Iniesta-Bonillo, M.Á. (2007), "The concept of perceived value: a systematic review of the research", Marketing theory, Vol. 7 No. 4, pp. 427-451. 
Scarpi, D., Pizzi, G. and Visentin, M. (2014), "Shopping for fun or shopping to buy: is it different online and offline", Journal of Retailing and Consumer Services, Vol. 21 No. 3, pp. 258-267.

Stake, R.E., (2005), “Qualitative Case Studies”. In: Denzin, N.K. and Lincoln, Y. (Eds.), The Sage Handbook of Qualitative Research, Sage, Thousand Oaks, CA. (pp. 443- 466).

Statista (2018), "E-commerce worldwide", Available at https://www.statista.com/study/10653/ e-commerce-worldwide-statista-dossier/ (accessed April 3rd, 2018). Original source: eMarketer.com.

Trevinal, A.M. and Stenger, T. (2014), "Toward a conceptualization of the online shopping experience", Journal of Retailing and Consumer Services, Vol. 21 No. 3, pp. 314-326.

Verhoef, P.C., Kannan, P. K. and Inman, J.J. (2015), "From multi-channel retailing to omnichannel retailing: introduction to the special issue on multi-channel retailing", Journal of Retailing, Vol. 91 No. 2, pp. 174-181.

Verhoef, P. C., Lemon, K. N., Parasuraman, A., Roggeveen, A., Tsiros, M., and Schlesinger, L. A. (2009), "Customer experience creation: Determinants, dynamics and management strategies", Journal of Retailing, Vol. 85 No.1, pp.31-41.

Wilding, R. (2013), “Multichannel or omni-channel?", Logistics and Transport Focus, Vol.15 No. 10, p. 44.

Yrjölä, M. (2015), Departures to Executive Decision Making in Omni-Channel Retailing, Acta Universitatis Tamperensis 2107, Tampere University Press: Tampere 2015.

Yrjölä, M., Spence, M. T. and Saarijärvi, H. (in press), "Omni-channel retailing: propositions, examples and solutions", The International Review of Retail, Distribution and Consumer Research, 1-18.

Zhang, J., Farris, P.W., Irvin, J.W., Kushwaha, T., Steenburgh, T.J. and Weitz, B.A. (2010), "Crafting integrated Multichannel Retailing strategies", Journal of Interactive Marketing, Vol. 24 No. 2, pp. 168-180. 
FIGURE 1. Preliminary conceptual framework of value creation through multiple-channel strategies

\begin{tabular}{|c|c|c|c|}
\hline $\begin{array}{c}\text { Consumer's } \\
\text { shopping } \\
\text { motivations } \\
\text { Utilitarian } \\
\text { Hedonic }\end{array}$ & $\begin{array}{c}\text { Company's } \\
\text { customer value } \\
\text { proposition } \\
\text { Company's } \\
\text { points of parity \& } \\
\text { points of difference } \\
\text { e.g. Collis \& Rukstad (2007); } \\
\text { Day \& Moorman (2010); } \\
\text { Anderson et al. (2007) } \\
\text { Babin et al. (1994); }\end{array}$ & $\begin{array}{c}\text { Company's } \\
\text { multiple-channel } \\
\text { sirschman \& Holbrook (1982) }\end{array}$ & $\begin{array}{c}\text { Multi-channel } \\
\text { Cross-channel } \\
\text { Omni-channel } \\
\text { e.g. Beck \& Rygl (2015); } \\
\text { Verhoef et al. (2015) }\end{array}$ \\
\hline Study purpose: to explore and analyze how retailers leverage \\
\hline multiple-channel strategies in relation to their customer value propositions. \\
\hline
\end{tabular}

FIGURE 2. The data generation process

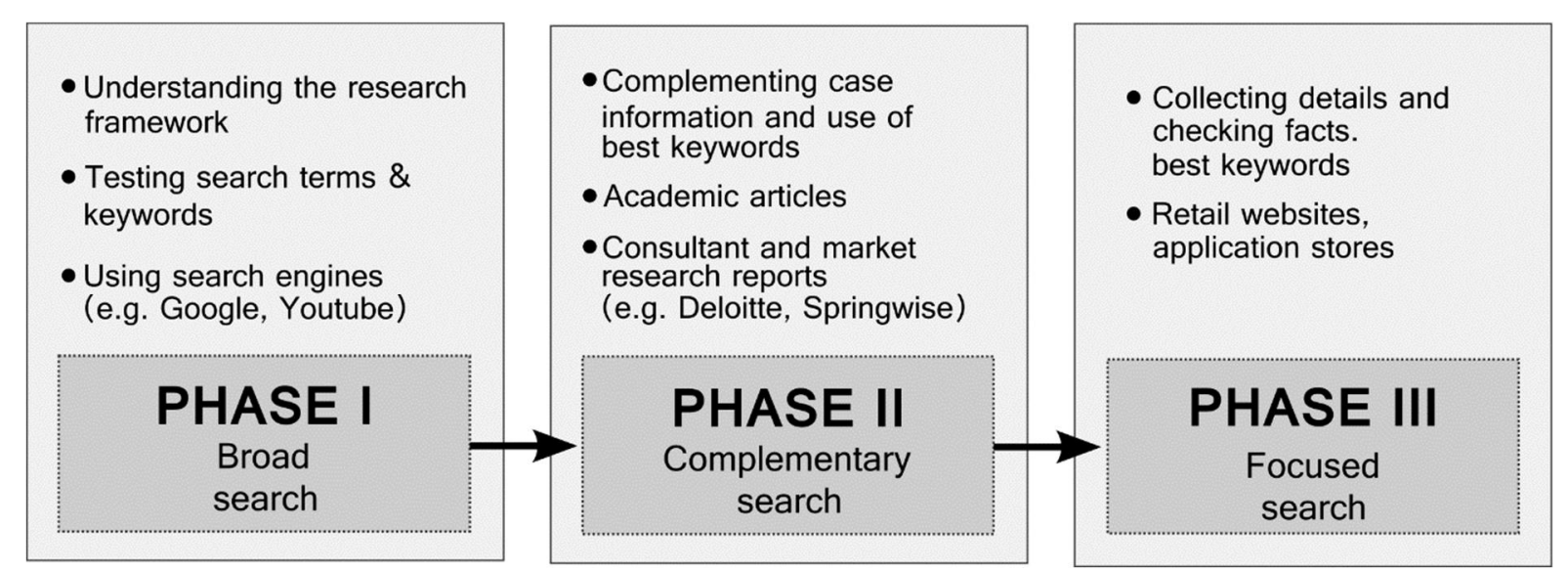


Table 1. The chosen illustrative case examples

\begin{tabular}{|c|c|c|c|}
\hline $\begin{array}{l}\text { Case example } \\
\text { (branch of retailing) }\end{array}$ & $\begin{array}{l}\text { Content of the customer value } \\
\text { proposition }\end{array}$ & $\begin{array}{l}\text { Multiple-channel } \\
\text { strategy }\end{array}$ & $\begin{array}{l}\text { Customer shopping } \\
\text { motivations }\end{array}$ \\
\hline $\begin{array}{l}\text { Power } \\
\text { (consumer electronics) }\end{array}$ & $\begin{array}{l}\text { Emphasis on low prices; prices } \\
\text { do not differ across channels } \\
\text { - Large selection }\end{array}$ & Multi-channel & Utilitarian \\
\hline $\begin{array}{l}\text { Masku } \\
\text { (furniture and decoration) }\end{array}$ & $\begin{array}{ll}\text { - } & \text { Superior products and large } \\
\text { selection } \\
\text { - } \\
\text { Knowledgeable customer } \\
\text { service and advice } \\
\text { - } \quad \text { Best value for the money }\end{array}$ & Multi-channel & Utilitarian \\
\hline $\begin{array}{l}\text { Nanso Group } \\
\text { (fashion and accessories) }\end{array}$ & $\begin{array}{ll}\text { - } & \text { Quality } \\
\text { - } & \text { Timeless design } \\
\text { - } & \text { Expressive patterns on brands } \\
& \text { and products }\end{array}$ & Multi-channel & Hedonic \\
\hline $\begin{array}{l}\text { The Home Depot } \\
\text { (DIY and renovation) }\end{array}$ & $\begin{array}{l}\text { Excellent service } \\
\text { More things to do with more } \\
\text { savings }\end{array}$ & Cross-channel & Utilitarian \\
\hline $\begin{array}{l}\text { Oasis } \\
\text { (fashion) }\end{array}$ & $\begin{array}{ll}\text { - } & \text { Customer looks and feels } \\
& \text { wonderful } \\
\text { - } & \text { Feminine, fun, and confident } \\
\text { - } & \text { Unique prints and colours } \\
\end{array}$ & Cross-channel & Hedonic \\
\hline $\begin{array}{l}\text { REI } \\
\text { (outdoor and camping) }\end{array}$ & $\begin{array}{ll}\text { - } & \text { Expert advice } \\
\text { - } & \text { High-quality service } \\
\text { - } & \text { High-quality products with a } \\
& 100 \% \text { guarantee } \\
\text { - } & \text { Inspiring, educational, and } \\
& \text { adventurous } \\
\text { - } & \text { Social responsibility }\end{array}$ & Cross-channel & Hedonic \\
\hline $\begin{array}{l}\text { Waitrose } \\
\text { (groceries) }\end{array}$ & $\begin{array}{ll}\text { - } & \text { Fresh and high-quality } \\
\text { groceries } \\
\text { - } & \text { Responsibility } \\
\text { - } & \text { Healthy } \\
\text { - } & \text { Positive shopping experience }\end{array}$ & Omni-channel & Hedonic \\
\hline $\begin{array}{l}\text { Jordan's Furniture } \\
\text { (furniture and decoration) }\end{array}$ & $\begin{array}{l}\text { - } \quad \text { memorable shopping } \\
\text { - } \quad \text { Broarience } \\
\text { - } \quad \text { Relaxing, easy, and fun prices } \\
\text { - "shopper-tainment" }\end{array}$ & Omni-channel & Hedonic \\
\hline $\begin{array}{l}\text { Rebecca Minkoff } \\
\text { (fashion) }\end{array}$ & $\begin{array}{ll}\text { - } & \text { Affordable luxury } \\
\text { - } & \text { Playful and trendy products } \\
\text { - } & \text { Empowering brand } \\
\text { - } & \text { Seamless shopping process }\end{array}$ & Omni-channel & Hedonic \\
\hline
\end{tabular}


Table 2. The value propositions of multi-, cross-, and omni-channel retailing

\begin{tabular}{|c|c|c|c|}
\hline & $\begin{array}{l}\text { MULTI-CHANNEL } \\
\text { Using more than one channel } \\
\text { whereby the customer cannot } \\
\text { trigger channel interaction and/or } \\
\text { the retailer does not control } \\
\text { channel integration }\end{array}$ & $\begin{array}{l}\text { CROSS-CHANNEL } \\
\text { Using more than one channel } \\
\text { whereby the customer can } \\
\text { trigger partial channel interaction } \\
\text { and/or the retailer controls } \\
\text { partial channel integration }\end{array}$ & $\begin{array}{l}\text { OMNI-CHANNEL } \\
\text { Using all channels } \\
\text { whereby the customer can } \\
\text { trigger full channel interaction } \\
\text { and/or the retailer controls } \\
\text { full channel integration }\end{array}$ \\
\hline $\begin{array}{l}\text { Locus of value } \\
\text { proposition }\end{array}$ & $\begin{array}{c}\text { PRODUCT } \\
\text { (price, selection) }\end{array}$ & $\begin{array}{l}\text { PROCESS } \\
\text { (convenience) }\end{array}$ & $\begin{array}{c}\text { EXPERIENCE } \\
\text { (customer personalization) }\end{array}$ \\
\hline $\begin{array}{r}\text { Examples of } \\
\text { utilitarian } \\
\text { and hedonic } \\
\text { channel benefits }\end{array}$ & $\begin{array}{c}\text { An alternative } \\
\text { channel for search } \\
\text { and purchase; customer } \\
\text { chooces appropriate } \\
\text { channel }\end{array}$ & $\begin{array}{c}\text { Desire for effiencient and } \\
\text { convenient shopping processes. } \\
\text { Ability to control } \\
\text { purchase process; } \\
\text { customer chooses } \\
\text { appropriate mixture of } \\
\text { channels }\end{array}$ & $\begin{array}{l}\text { Seamless customer } \\
\text { experience; customer } \\
\text { chooses most inspriring } \\
\text { and effective } \\
\text { customer experience }\end{array}$ \\
\hline $\begin{array}{r}\text { Examples of } \\
\text { channel } \\
\text { strategy } \\
\text { characteristics }\end{array}$ & $\begin{array}{c}\text { Highlighting channel-specific } \\
\text { benefits, e.g. expert advice } \\
\text { (store), or 24-hour availability } \\
\text { (online); } \\
\text { Executing channel-specific } \\
\text { advertising efforts, gift cards, } \\
\text { and loyalty programs; } \\
\text { Highlighting the superiority } \\
\text { of products, price or selection }\end{array}$ & $\begin{array}{c}\text { Facilitating convenient } \\
\text { transactions through mobile } \\
\text { payment and electronic receipts; } \\
\text { Enabling in-store access to } \\
\text { additional product information } \\
\text { (customer reviews, prices, } \\
\text { availability), e.g. through electronic } \\
\text { barcodes or mobile scanning apps; } \\
\text { Enabling convenient product } \\
\text { logistics, such as picking up or } \\
\text { returning online orders in store; } \\
\text { Encouraging in-store } \\
\text { showrooming, e.g. focusing } \\
\text { transactions and logistics online } \\
\text { helping customers navigate } \\
\text { to store and in-store }\end{array}$ & $\begin{array}{l}\text { Enabling customers to store } \\
\text { and access their own loyalty } \\
\text { program data, wish lists and } \\
\text { purchase history across channels; } \\
\text { Utilizingnew technologies } \\
\text { and media, such as digital fitting } \\
\text { rooms and social media, to } \\
\text { orchestrate hedonic and } \\
\text { personalized shopping experiences; } \\
\text { Integrating data collection and } \\
\text { analysis across channels, e.g. } \\
\text { serving customers through } \\
\text { personalized infromation } \\
\text { regardless of which channels } \\
\text { they have employed. }\end{array}$ \\
\hline $\begin{array}{r}\text { Case } \\
\text { examples }\end{array}$ & $\begin{array}{l}\text { Power, Masku \& } \\
\text { Nanso Group }\end{array}$ & $\begin{array}{l}\text { Home Depot, } \\
\text { Oasis \& REI }\end{array}$ & $\begin{array}{c}\text { Waitrose, Jordan's Furniture } \\
\text { Rebecca Minkoff }\end{array}$ \\
\hline
\end{tabular}


Appendix I. Example of keywords used in the data generation

\begin{tabular}{|c|c|c|c|}
\hline Keywords & Domain & $\begin{array}{l}\text { Phase of data } \\
\text { generation }\end{array}$ & Results \\
\hline $\begin{array}{l}\text { "examples of omni- } \\
\text { channel retailers" }\end{array}$ & Google & 1: Broad search & $\begin{array}{l}31 \text { case examples, out } \\
\text { of which } 7 \text { were chosen } \\
\text { for further analysis }\end{array}$ \\
\hline $\begin{array}{l}\text { "best omni-channel } \\
\text { retailers" }\end{array}$ & Google & 1: Broad search & $\begin{array}{l}24 \text { case examples, out } \\
\text { of which } 7 \text { were chosen } \\
\text { for further analysis }\end{array}$ \\
\hline $\begin{array}{l}\text { "omni-channel } \\
\text { experience" }\end{array}$ & $\begin{array}{l}\text { Retail Customer } \\
\text { Experience }\end{array}$ & $\begin{array}{l}\text { 2: Complementary } \\
\text { search }\end{array}$ & $\begin{array}{l}8 \text { case examples, out of } \\
\text { which } 2 \text { were chosen } \\
\text { for further analysis }\end{array}$ \\
\hline "connected store" & $\begin{array}{l}\text { Retail Customer } \\
\text { Experience }\end{array}$ & $\begin{array}{l}\text { 2: Complementary } \\
\text { search }\end{array}$ & $\begin{array}{l}6 \text { case examples, out of } \\
\text { which } 1 \text { was chosen for } \\
\text { further analysis }\end{array}$ \\
\hline $\begin{array}{l}\text { "(retailer name) omni- } \\
\text { channel" }\end{array}$ & Google & 3: Focused search & $\begin{array}{l}\text { Details on the specific } \\
\text { case }\end{array}$ \\
\hline $\begin{array}{l}\text { "(retailer name) mobile } \\
\text { app" }\end{array}$ & Google & 3: Focused search & $\begin{array}{l}\text { Details on the specific } \\
\text { case }\end{array}$ \\
\hline
\end{tabular}


Appendix II. Initial cases

\begin{tabular}{|c|c|c|}
\hline Retailer & Short case description & Information sources \\
\hline Bloomingdale's & $\begin{array}{l}\text { The department store Bloomingdale's has a value proposition emphasizing uniqueness and hedonic } \\
\text { value: "like no other store in the world." Customers can shop online, mobile, or at stores. The retailer's } \\
\text { mobile app allows customers to store their loyalty card information, scan products, and have their } \\
\text { purchases delivered home. In store, tablets complement the shopping experience. Both online and } \\
\text { offline customers can use a swivel 3D fitting room through which they can virtually try on items. }\end{array}$ & $\begin{array}{l}\text { http://www.chainstoreage.com/article/and-top- } \\
\text { omnichannel-retailers-are } \\
\text { http://www1.bloomingdales.com/about/compa } \\
\text { ny/press/detail.ognc?newsID=139 }\end{array}$ \\
\hline Rebecca Minkoff & $\begin{array}{l}\text { Rebecca Minkoff retails affordable, playful and elegant luxury clothing, shoes, and accessories for } \\
\text { trendy millennial females. Regarding channel strategy, the retailer provides a seamless shopping } \\
\text { experience using online, mobile, and offline channels. The New York flagship store offers digital } \\
\text { screens with interactive fitting rooms that can send data to be viewed online on other channels. } \\
\text { Rebecca Minkoff also offers a virtual fitting room application. }\end{array}$ & $\begin{array}{l}\text { http://www.insider-trends.com/omnichannel- } \\
\text { retail-companies/ } \\
\text { https://www.rebeccaminkoff.com/ } \\
\text { http://digiday.com/brands/rebecca-minkoff- } \\
\text { digital-store/ }\end{array}$ \\
\hline Boulanger & $\begin{array}{l}\text { The French home electronics retailer, Boulanger, emphasizes professional, convenient, and dedicated } \\
\text { service. The retailer operates online, mobile, and physical store channels. Customers can order online } \\
\text { and pick up at the store. In-store, the products displayed have electronic barcodes enabling customers } \\
\text { to compare prices and read reviews. Boulanger also utilizes mobile payments and electronic receipts. }\end{array}$ & $\begin{array}{l}\text { http://www.retailcustomerexperience.com/blog } \\
\text { s/3-surefire-ways-to-tell-if-a-retail-store-is- } \\
\text { omnichannel/ }\end{array}$ \\
\hline Bonobos & $\begin{array}{l}\text { The American retailer, Bonobos, designs and sells men's clothing and accessories. The value } \\
\text { proposition emphasis is on well-fitting products and a convenient shopping experience. According to } \\
\text { the retailer, shopping for clothes is usually inconvenient, which is why they focus on making the } \\
\text { process easy and fun. The retailer focuses its transactions in its online channel, while its physical } \\
\text { stores act as showrooms. Customers can make reservations for receiving guidance in the stores. }\end{array}$ & $\begin{array}{l}\text { http://www.businessinsider.com/bonobos- } \\
\text { opened-a-store-where-you-cant-physically- } \\
\text { buy-anything-2015-7 } \\
\text { http://www.forbes.com/sites/barbarathau/2015/ } \\
\text { 07/08/bonobos/\#34ceab587977 }\end{array}$ \\
\hline Nordstrom & $\begin{array}{l}\text { Nordstrom, an American upscale department store, utilizes physical stores, online and mobile } \\
\text { channels, and a print catalogue. Nordstrom's value proposition consists of dedicated customer service } \\
\text { and a fresh and relevant fashion experience. The retailer builds an omni-channel strategy via linking } \\
\text { different channels to offer a personalized and seamless shopping experience. In the mobile channel, }\end{array}$ & $\begin{array}{l}\text { http://diginomica.com/2015/08/14/omni- } \\
\text { channel-is-about-customers-not-channels-at- } \\
\text { nordstrom/ }\end{array}$ \\
\hline
\end{tabular}




\begin{tabular}{|c|c|c|}
\hline & $\begin{array}{l}\text { customers can check whether the right size and color version of the product is available in the nearest } \\
\text { stores. The retailer is adding digital mirrors that enable customers to compare outfits more easily. }\end{array}$ & $\begin{array}{l}\text { http://fortune.com/2014/11/25/nordstrom-ebay- } \\
\text { fitting-rooms/ }\end{array}$ \\
\hline Neiman Marcus & $\begin{array}{l}\text { Neiman Marcus is a high-end department store retailer that offers high-quality apparel, cosmetics, } \\
\text { and home decor. The retailer, operating online, mobile, and offline channels, reports having an } \\
\text { integrated store and online experience. Product returns from any channel can be made at physical } \\
\text { stores. The in-store experience is enhanced by digital mirrors. According to the retailer, an omni- } \\
\text { channel strategy is not about offering the same features in all channels, but rather about removing } \\
\text { channel boundaries and personalizing the customer experience. }\end{array}$ & $\begin{array}{l}\text { https://www.internetretailer.com/2016/09/22/n } \\
\text { eiman-marcus-focuses-omnichannel- } \\
\text { improvements } \\
\text { https://consumerist.com/2015/05/11/neiman- } \\
\text { marcus-nordstrom-other-retailers-trying-out- } \\
\text { smart-fitting-room-mirrors/ }\end{array}$ \\
\hline John Lewis & $\begin{array}{l}\text { John Lewis is a UK-based department store chain focusing on home appliances, electronics, beauty, } \\
\text { fashion, and children's products. The value proposition emphasis is on a superior shopping experience } \\
\text { enabled by high quality services such as online buyer's guides for different product categories. The } \\
\text { channels used include online, mobile, digital catalogues, and physical stores. There are different } \\
\text { mobile applications for smartphones and for tablets. A "click and collect" service with next day pick } \\
\text { up is offered for mobile and online customers. }\end{array}$ & $\begin{array}{l}\text { http://www.smartinsights.com/online-brand- } \\
\text { strategy/multichannel-strategies/omnichannel- } \\
\text { examples/ } \\
\text { http://internetretailing.net/2016/09/john-lewis- } \\
\text { partnership-continues-invest-omnichannel- } \\
\text { half-year-sales-rise-profits-fall/ }\end{array}$ \\
\hline Sephora & $\begin{array}{l}\text { The French cosmetics retailer, Sephora, aims to be a forerunner in beauty and aesthetics by innovating } \\
\text { and offering prestigious products, expert advice, and an interactive shopping environment. Sephora } \\
\text { operates physical stores, online stores, and mobile apps. In store, Sephora offers make-up lessons and } \\
\text { personal expert appointments, while the mobile app features tutorials, product reviews, } \\
\text { recommendations and demonstrations, and lessons in make-up techniques. The app also enables } \\
\text { customers to renew previous orders and enables virtual product testing. }\end{array}$ & $\begin{array}{l}\text { http://omnichannel.me/connected-store- } \\
\text { spotlight-sephora-flash/ } \\
\text { http://etailwest.wbresearch.com/how-sephora- } \\
\text { integrates-retail--online-marketing }\end{array}$ \\
\hline Oasis & $\begin{array}{l}\text { The UK-based fashion retailer, Oasis, strives to make its customers look and feel excellent. They offer } \\
\text { customers unique prints, personal stylist services, and feminine, confident clothing. Oasis operates } \\
\text { physical stores and online and mobile channels. The mobile app features a product scanner, new } \\
\text { product launches, offers, customer reviews, and fashion videos. Online or mobile, the customers can }\end{array}$ & $\begin{array}{l}\text { http://multichannelmerchant.com/must- } \\
\text { reads/5-excellent-examples-omnichannel- } \\
\text { retailing-done-right-14052014/ }\end{array}$ \\
\hline
\end{tabular}




\begin{tabular}{|c|c|c|}
\hline & $\begin{array}{l}\text { use a "find in store" feature to locate sold-out products in stores. Employees in physical stores all } \\
\text { have tablet devices that enable them to give customers real-time product information. }\end{array}$ & \\
\hline The Home Depot & $\begin{array}{l}\text { The Home Depot is an American retailer offering do-it-yourself and renovation products and } \\
\text { materials as well as services. The retailer aims to be distinctive through excellent service and by being } \\
\text { a socially responsible corporation. The Home Depot reports having online, mobile, and in-store } \\
\text { channels that are integrated in functionality. For instance, the retailer's mobile app functions well } \\
\text { with physical stores; mobile purchases can be picked up from the stores and the app features store } \\
\text { layouts. Online purchases can also be returned to physical stores. }\end{array}$ & $\begin{array}{l}\text { http://etaileast.wbresearch.com/how-home- } \\
\text { depot-nails-omnichannel-supply-chain- } \\
\text { fulfillment } \\
\text { https://www.internetretailer.com/2016/08/18/h } \\
\text { ome-depot-builds-its-omnichannel-efforts-q2 }\end{array}$ \\
\hline Waitrose & $\begin{array}{l}\text { The UK-based supermarket retailer, Waitrose, bases its value proposition on fresh high-quality food } \\
\text { that has transparent source and ingredients and aims to help its customers make healthier choices. The } \\
\text { retailer operates offline, online and mobile channels with an emphasis on a seamless customer } \\
\text { experience. Stores feature dining areas, interactive digital kiosks and tablets that complement the } \\
\text { shopping experience. The mobile channel features a mobile magazine with inspirational recipes, and } \\
\text { a "Quick Check" app for shopping in-store. }\end{array}$ & $\begin{array}{l}\text { http://internetretailing.net/2014/05/how- } \\
\text { waitrose-is-using-omnichannel-in-a-strategy- } \\
\text { aimed-at-setting-itself-apart/ }\end{array}$ \\
\hline REI & $\begin{array}{l}\text { Recreational Equipment, Inc. (REI) is an American retailer of outdoor, travel, and sports equipment } \\
\text { and services that attempts to inspire, teach and fit customers for their lifelong outdoor adventure. REI } \\
\text { promises customers that each channel will deliver the same level of customer service, product } \\
\text { information, and knowledge. The company utilizes two online stores, a phone and mail order service, } \\
\text { physical stores, and a mobile application. REI's mobile app enables customers to browse products, } \\
\text { contact clerks, and scan barcodes and look up detailed product information. }\end{array}$ & $\begin{array}{l}\text { https://www.internetretailer.com/commentary/ } \\
\text { 2016/02/02/top-10-omnichannel-retail-trends- } \\
2016 \\
\text { http://www.tompkinsinc.com/top-10- } \\
\text { omnichannel-retailers/ } \\
\text { https://www.rei.com/ }\end{array}$ \\
\hline Apple & $\begin{array}{l}\text { The American consumer electronics company, Apple, provides customers with a simple and easy } \\
\text { user-centered consumption experience in online, in-store, and mobile channels. Apple stores offer } \\
\text { customers expert advice, troubleshooting, and repair in their "Genius Bar" sections. Customers can } \\
\text { use Apple's mobile app to make reservations for this service. The app features a personalized way to }\end{array}$ & $\begin{array}{l}\text { http://www.apple.com/ } \\
\text { http://www.chainstoreage.com/article/three- } \\
\text { ways-apple-impacting-omnichannel }\end{array}$ \\
\hline
\end{tabular}




\begin{tabular}{|c|c|c|}
\hline & $\begin{array}{l}\text { purchase Apple products and add-on gear by offering product recommendations, notifications, a store } \\
\text { locator, and an identifier for picking up mobile and online purchases at the store. }\end{array}$ & $\begin{array}{l}\text { http://www.netimperative.com/2015/09/right- } \\
\text { to-reply-apples-explosion-of-omni-channel- } \\
\text { media/ }\end{array}$ \\
\hline Tesco & $\begin{array}{l}\text { The UK-based retailer, Tesco's value proposition emphasizes superior customer service, which is } \\
\text { summarized in its slogan: "Every little helps." Tesco operates online, mobile, and offline channels. } \\
\text { The online channel offers a "click and collect" feature that enables customers to pick up their online } \\
\text { orders from physical stores. Tesco offers separate apps for groceries, banking, loyalty cards, and } \\
\text { photographs. The grocery app lets the customer search for recipes, create shopping lists, add items to } \\
\text { their favorites, place orders, and receive special offers. }\end{array}$ & $\begin{array}{l}\text { http://www.tesco.com/apps/ } \\
\text { https://itunes.apple.com/gb/app/tesco- } \\
\text { groceries-for-iphone/id389581236?mt=8 } \\
\text { http://www.retail-focus.co.uk/features/966- } \\
\text { tesco-watford-extra-supermarket-of-the-future }\end{array}$ \\
\hline $\begin{array}{l}\text { Jordan's } \\
\text { Furniture }\end{array}$ & $\begin{array}{l}\text { Jordan's Furniture is an American furniture retailer with a value proposition focused on offering an } \\
\text { experience rather than a mere store visit: the shopping process itself is easy, relaxing, and fun. } \\
\text { Jordan's Furniture operates online and offline channels. Online orders can be delivered to the home } \\
\text { or picked up at the store. The physical store environment consists of different themed "streets" and } \\
\text { features various experiences such as an IMAX 3D movie theatre. }\end{array}$ & $\begin{array}{l}\text { http://www.jordans.com/room-planner } \\
\text { https://hbr.org/2011/12/the-future-of-shopping } \\
\text { http://www.makeuseof.com/tag/jordans- } \\
\text { furnishing-rooms/ }\end{array}$ \\
\hline Nanso Group & $\begin{array}{l}\text { Nanso Group is a Finnish manufacturer and retailer of knitted fabrics, pantyhose, and socks. The } \\
\text { brand embodies quality, expressive prints, timeless design, and ecological responsibility. Nanso } \\
\text { Group operates online and offline channels, but online purchases cannot be ordered for in-store pick } \\
\text { up or returned to stores. Further, the online store has its own customer loyalty program that does not } \\
\text { work with the physical stores, which have their own loyalty program. }\end{array}$ & $\begin{array}{l}\text { http://nansoshop.com/ } \\
\text { http://www.nansogroup.com/en/ }\end{array}$ \\
\hline Masku & $\begin{array}{l}\text { Masku, a Finnish furniture and decoration retailer, offers customers superior products, large } \\
\text { selections, and good value for the money with an emphasis on knowledgeable customer service } \\
\text { personnel who can offer customers valuable advice based on their personal situations. Masku operates } \\
\text { online and offline channels. Online purchases cannot be picked up at the physical store, while some } \\
\text { items (e.g. gift cards) can only be purchased from the physical store. }\end{array}$ & https://www.masku.com/ \\
\hline
\end{tabular}




\begin{tabular}{|l|l|l|}
\hline Power & $\begin{array}{l}\text { The Nordic home electronics retailer, Power, employs a strategy of aggressive pricing. The value } \\
\text { proposition emphasis is on low prices, large selection, and prices that are the same across both } \\
\text { channels (stores and website). Online orders cannot be picked up or returned at physical stores. }\end{array}$ & $\begin{array}{l}\text { httpow.fi// } \\
\text { Kruunukaluste }\end{array}$ \\
\hline $\begin{array}{l}\text { The Finnish furniture retailer, Kruunukaluste, offers individual, high-quality solutions for home } \\
\text { operates physical stores and online channels. Larger online orders can be delivered to the home or } \\
\text { picked up at any of the company's three warehouses, while smaller orders are delivered to the nearest } \\
\text { pick-up point. }\end{array}$ & hrunukaluste.fi/ \\
\hline
\end{tabular}

